4. Karlin, M.I. (2014). Podatkove rehuliuvannia mizhbiudzhetnykh vidnosyn v krainakh EU: dosvid dlia Ukrainy. [Tax regulation of intergovernmental fiscal relations in the EU: experience for Ukraine]. Ekonomichnyi forum, 3 , 254-260 [in Ukrainian].

5. On Approval of the Methodology for the Formation of Capable Territorial Communities: Resolution of the Cabinet of Ministers of Ukraine dated April 8, 2015, № 2014 (2015, May 6). Uriadovyi kurier, 9 [in Ukrainian].

6. On approving the distribution of the amount of subvention from the state budget to local budgets for the formation of infrastructure of united territorial communities in 2018: by the CMU from 04.04.2018 № 993 (2018, April 6). Uriadovyi kurier, 10 [in Ukrainian].

7. Hromadska dumka naselennia shchodo reformy detsentralizatsii [Public opinion on decentralization reform]. Retrieved from https:// dif.org.ua/article/detsentralizatsya-dosyagnennya-problemi-otsinki-gromadyan [in Ukrainian].

8. Dyakonenko, O.I. (2018) Influence of financial decentralization on the development of rural settlements in Ukraine [Influence of financial decentralization on the development of rural settlements in Ukraine]. Demohrafiia ta sotsialna ekonomika, 3, 160-174 [in Ukrainian].

Стаття надійшла до редакції 15.06.2019 р.

УДК 336.330

Стащук Олена, доктор економічних наук, доцент, Східносвропейський національний університет імені Лесі Українки, професор кафедри фінансів та кредиту, м. Луцьк; ORCID ID 0000-0003-2622-7353 e-mail: helenastashchuk@gmail.com

https://doi.org/10.29038/2411-4014-2019-03-127-132

\title{
КРЕДИТУВАННЯ ЯК МЕТОД ФІНАНСУВАННЯ ЖИТЛОВОГО БУДІВНИЦТВА
}

У статті розглянуто проблеми фінансування житлового будівництва та систематизовано основні методи й форми його фінансування. Обгрунтовано найбільш актуальні форми кредитування житлового будівництва 3 урахуванням їх переваг та недоліків. Досліджено тенденції інвестування будівництво житла в Україні. У роботі виявлено проблемні аспекти застосування облігаційних позик, банківських кредитів та іпотечних кредитів у практиці фінансування житлового будівництва. Ідентифіковано переваги та недоліки іпотечного кредитування у житловому будівництві. Запропоновано напрями реалізації політики житлового будівництва 3 метою підвищення інвестиційної привабливості житлової сфери та використання сучасних альтернативних форм фінансування житлового будівництва в Україні.

Ключові слова: фінансування, житлове будівництво, іпотечний кредит, облігаційна позика, банківський кредит; інвестиції у будівництво житла.

Стащук Елена, доктор экономических наук, доцент, Восточноевропейский национальный университет имени Леси Украинки, профессор кафедры финансов и кредита, г. Луцк

\section{КРЕДИТИРОВАНИЕ КАК МЕТОД ФИНАНСИРОВАНИЯ ЖИЛИЩНОГО СТРОИТЕЛЬСТВА}

В статье рассмотрены проблемы финансирования жилищного строительства и систематизированы основные методы и формы его финансирования. Обоснованно наиболее актуальные формы кредитования жилищного строительства с учетом их преимуществ и недостатков. Исследована тенденции инвестирования строительства жилья в Украине. В работе выявлены проблемные аспекты применения облигационных займов, 
банковских кредитов и ипотечных кредитов в практике финансирования жилищного строительства. Идентифицировано преимущества и недостатки ипотечного кредитования в жилищном строительстве. Предложены направления реализации политики жилищного строительства с целью повышения инвестиционной привлекательности жилищной сферы и использования современных альтернативных форм финансирования жилищного строительства в Украине.

Ключевые слова: финансирование, жилищное строительство, ипотечный кредит, облигационный заем, банковский кредит; инвестиции в строительство жилья

Olena Stashchuk, Doctor of Economic Sciences, Docent, Lesia Ukrainka Eastern European National University, Professor of Finance and Credit Department, Lutsk

\section{CREDIT AS A METHOD OF FINANCING HOUSING}

Introduction. Housing as a branch of the economy is intended to satisfy one of the rights declared by the Constitution of Ukraine - the right to own housing. The provision of such a right by the state is possible provided that an effective housing policy is developed and implemented. As a consequence, an effective housing ceiling will also promote the development of other related sectors of the economy.

The purpose of the article is to provide a theoretical justification for the feasibility of using certain forms of lending in the practice of housing. Achieving this goal requires the following tasks: to systematize forms of crediting housing construction; to conduct an analysis of the state of housing construction in Ukraine and identify problems of its development; to identify the features of mortgage lending as a financing tool for housing construction.

Results. The article deals with the peculiarities of such forms of credit financing of housing construction as a bond loan, bank lending and mortgage lending. The main advantages and disadvantages of using such forms of financing in the practice of construction of residential real estate have been identified. The trends of credit financing of housing construction in Ukraine during 2014 - 2018 have been established. The role of flow lending in housing finance has been identified, and bottlenecks in the development of mortgage lending in Ukraine have been identified.

Conclusions. The use of borrowed resources as a source of housing finance has indisputable benefits, since it contributes primarily to the socio-economic development of the country and promotes the right of every citizen to own a home. However, when choosing a form of housing loan, it is advisable to be guided by the advantages and disadvantages of each individual form for a particular residential real estate object. The presence of identified problematic aspects in the housing finance system indicates the need for continuous study of the peculiarities of the application of separate sources of financing for the construction of residential real estate objects.

Key words: financing, housing, mortgage, bond, bank loan; investment in housing construction.

Постановка проблеми у загальному вигляді та іiї зв'язок 3 важливими науковими та практичними завданнями. Житлове будівництво як галузь економіки покликане задовольнити одне iз задекларованих Конституцією України прав - право на власне житло. Забезпечення такого права державою можливе за умови розробки та реалізації ефективної політики житлового будівництва. Як наслідок, ефективна житлова потілика сприятиме й розвитку інших суміжних галузей економіки. Нині в Україні спостерігається зниження обсягів житлового будівництва, моральний та фізичний знос об'єктів житлової нерухомості, падіння рівня житлової забезпеченості та низький рівень доходів населення. 3 іншої сторони, будівництво житлової нерухомості є високо затратним як 3 фінансових аспектів, так і з часових. Усе це свідчить про необхідність формування комплексного підходу щодо ефективної реалізації політики житлового будівництва в Україні. Особливу увагу необхідно приділити фінансуванню будівництва житла й його основним методам та формам.

Аналіз останніх досліджень, у яких започатковано вирішення проблеми. Сиситематизація наукової літератури дає підстави стверджувати, що проблематика фінансування житлового будівництва не є новою як у вітчизняній, так й у зарубіжній науці. Окремі пропозиції щодо особливостей використання тих чи інших форм фінансування будівництва житла можна спостерігати у роботах таких вчених-економістів, як: В. Д. Базилевич, О. Т. Євтух, В. І. Кравченко, І. М. Кучеренко, К. В. Паливода, Н. В. Новіков, Н. П. Погорєльцева, І. А. Рахман, А. Г. Реут, О. В. Сударенко, Л. М. Черенько, О. Н. Юркевич та інших. Разом 3 тим, подальшого дослідження вимагають питання залучення позикових ресурсів 3 метою фінансування будівництва об'єктів житлової нерухомості. Водночас, потребують теоретичного дослідження особливості застосування 
облігаційної позики в умовах нерозвиненості вітчизняного фондового ринку. Невирішеними залишаються й окремі аспекти іпотечного кредитування в Україні.

Метою дослідження $\epsilon$ теоретичне обгрунтування доцільності застосування окремих форм кредитування у практиці житлового будівництва. Досягнення визначеної мети потребує вирішення таких завдань: систематизувати форми кредитування будівництва житла; провести аналіз стану житлового будівництва в Україні та виявити проблеми його розвитку; ідентифікувати особливості здійснення іпотечного кредитування як інструмента фінансування будівництва житла.

Виклад основного матеріалу. Підгрунтям системи фінансування житлового будівництва $\epsilon$ механізм його фінансового забезпечення. Процес фінансування у сфері будівництва житла відбувається $з$ використанням певних методів, форм, інструментів та передбачає забезпечення підприємств-забудовників оптимальним обсягом грошового капіталу, що використовується у процесі створення об'єктів житлової нерухомості. Огляд наукової літератури дозволив нам систематизувати методи фінансування житлового будівництва, серед яких варто відзначити такі: 1) самофінансування; 2) пайове фінансування; 3) кредитне фінансування; 4) бюджетне фінансування; змішане фінансування.

Динаміку структури капітальних інвестицій в Україні за джерелами фінансування зображено на рисунку 1.

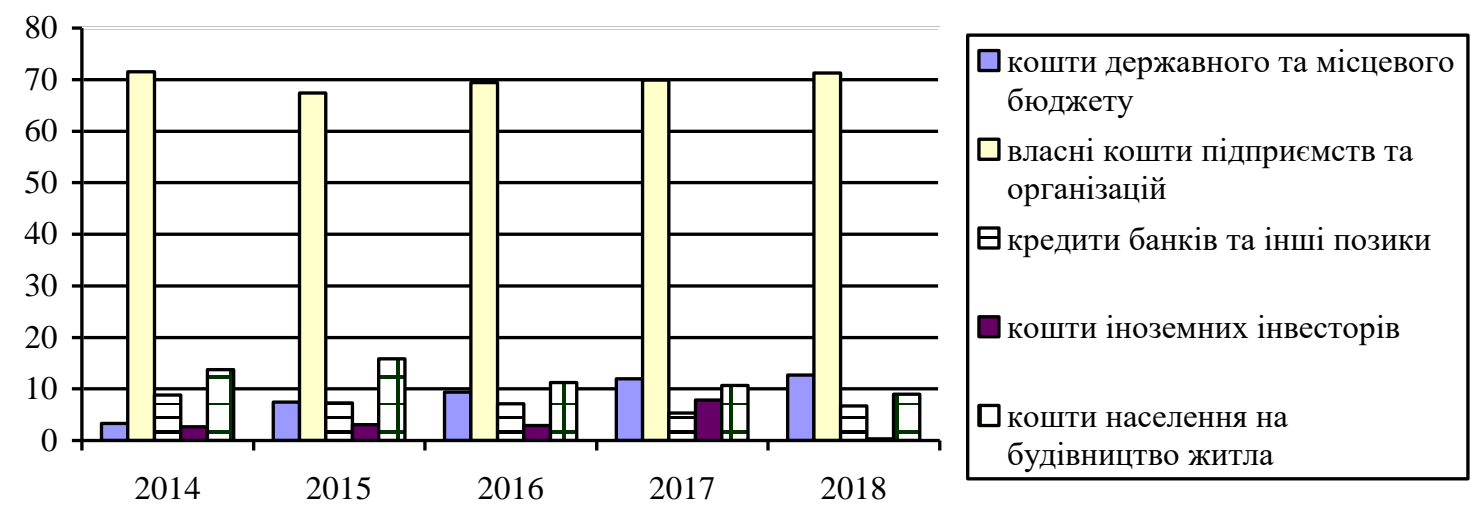

Рис. 1. Структура капітальних інвестицій в Україні у 2014 - 2018 роках. *

*Джерело: Складено автором на основі [6]

Як бачимо з рисунку 1, у структурі джерел фінансування будівництва в Україні протягом 2014 2018 років превалюють власні кошти підприємств та організацій та у всіх досліджуваних періодах їх величина становить в межах $70 \%$ від загального обсягу інвестування. Майже незмінною залишається й частка коштів населення, спрямованих на будівництво житла - така частка протягом 2014 - 2018 років становила близько $10 \%$ і лише у 2014 році частка таких ресурсів у структурі усіх джерел фінансування перевищила $15 \%$.на вкрай низькому рівні знаходиться обсяг капітальних інвестицій за рахунок коштів іноземних інвесторів - максимальний рівень їх частки у структурі усіх джерел фінансування капітальних інвестицій спостерігався у 2017 році та становив 7,8 \%, а піку свого падіння таке джерело фінансування набуло у 2018 році. Що стосується фінансування капітальних інвестицій за рахунок кредитів банків та інших позик, то його частка у структурі усіх джерел фінансування розподілялася наступним чином за роками: у 2014 році - 8,8\%, у 2015 році 7,3\%, у 2016 році $-7,1 \%$, у 2017 році $-5,3 \%$, у 2018 році $-6,7 \%$.

Безперечно, зниження обсягів капітальних інвестицій за рахунок позикових ресурсів $\epsilon$ негативним аспектом у розвитку житлового будівництва, проте це стало наслідком об'єктивних причин та негативних зрушень в економіці: висока відсоткова ставка за кредитами, низький рівень реальних доходів населення; високий термін окупності інвестиційних проектів; наявність військових дій в країні тощо. Проте, використання у практиці житлового будівництва кредитних ресурсів $\epsilon$ ефективним інструментом розвитку економіки в цілому. Відзначимо, що кредитне фінансування житлового будівництва здійснюється шляхом отримання забудовником позики на обмежений термін зі сплатою відсотків за ії користування. Найбільш типовими формами кредитного фінансування 
житла є емісія облігацій, банківські позики, іпотечні кредити.

Облігаційна позика є джерелом фінансування житлового будівництва шляхом емісії облігацій. Такий інструмент залучення фінансових ресурсів забудовниками є достатньо привабливим з точки зору мінімізації оподаткування, оскільки фінансові ресурси, отримані від реалізації облігацій не включаються до складу валових доходів, проте відсотки за обслуговування таких облігацій $є$ елементом валових витрат забудовників. Окрім того, операції з купівлі-продажу облігацій не підлягають оподаткуванню податком на додану вартість, а сам механізм випуску облігацій чітко регламентується Національною комісією з цінних паперів та фондового ринку України [1]. Варто погодитися із О. А. Ломачинською у тому, що основною перевагою такого фінансового інструменту $\epsilon$ те, що він $\epsilon$ найбільш діючим i ефективним, дозволяє, не перерозподіляючи власність, акумулювати кошти інвесторів і забезпечувати підприємству доступ на ринок капіталів без загрози подальшого втручання інвесторів (власників облігацій) в управління його поточною фінансовогосподарською діяльністю [8].

Разом 3 тим, недоліками такої форми фінансування є правові колізії щодо отримання житла інвесторами, а скористатися облігаційною позикою як джерелом формування фінансових ресурсів можуть лише ті забудовники, які функціонують у формі акціонерних товариств. Фінансування житлового будівництва за рахунок облігаційної позики $є$ доцільним, якщо: 1) відсоткова ставка за облігацією буде нижчою, ніж рівень прибутковості 3 використанням позикових коштів; 2) підприємство-забудовник немає проблем із ліквідністю та прибутковістю; 3) ринок об'єктів житлової нерухомості знаходиться на стадії зростання; 4) необхідно зберегти контроль над управлінням підприємством.

Банківський кредит на будівництво житла надається забудовникам, як правило, у грошовій формі та на умовах платності, строковості, поверненості, застави й цільового використання. Перевагами такої форми фінансування є також оптимізація оподаткування податком на прибуток підприємств-забудовників. Облігації - це найбільш вдала схема з точки зору оподаткування, адже в момент залучення коштів немає ніяких податків, їх виникнення переноситься на дату укладання основного договору, тобто на дату погашення облігацій [2]. Проте, вважаємо, негативними аспектами такої позики є обмежений термін іiі використання, висока вартість залучених коштів, потреба у заставі.

3 метою розширення джерел фінансування будівництва житла та залучення заощаджень населення в економічну систему через будівництво житлової нерухомості, необхідно звернути увагу на розвиток іпотечного кредитування. Цей вид кредитів вважається одним із найбільш надійних через використання застави нерухомості [3]. Іпотечний кредит відображає економічні відносини 3 приводу надання позик під заставу нерухомого майна. Іпотечне кредитування не використовується у процесі будівництва нового житла, оскільки потребує застави за таким кредитом. Відзначимо, що в Україні обсяги іпотечного кредитування протягом 2014-2017 років мають тенденцію до зниження, а саме їх величина у 2014 році становила 56270 млн. грн., а у 2017 році - 43626 млн. грн. [4]. Основними чинниками таких процесів, на наш погляд, $є$ низький рівень доходів населення, відносно висока відсоткова ставка за іпотечним кредитом, низька ліквідність об'єкта іпотеки. Загалом, кредитне фінансування житлового будівництва доцільно застосовувати в процесі фінансування об’єктів 3 високим рівнем доходності та низьким терміном окупності. Водночас, О. Дмітрієва стверджує, що на шляху до ефективного розвитку іпотечного кредитування стоять [7]:

1) висока вартість наявної ресурсної бази та високий рівень відсоткових ставок за кредитами (у межах $20-25 \%$ річних);

2) відсутність джерел довгострокових ресурсів для фінансування іпотеки (раз на 4-5 років в країні спостерігаються кризові явища, які призводять до суттєвого зростання вартості ресурсної бази, що в свою чергу призводить до від’ємної процентної маржі за раніше виданими кредитами);

3) недоліки законодавчо-нормативної бази, які полягають в недосконалому регулюванні процедур звернення стягнення на предмети іпотеки.

Динаміка кількості укладених іпотечних договорів представлена на рисунку 2. 


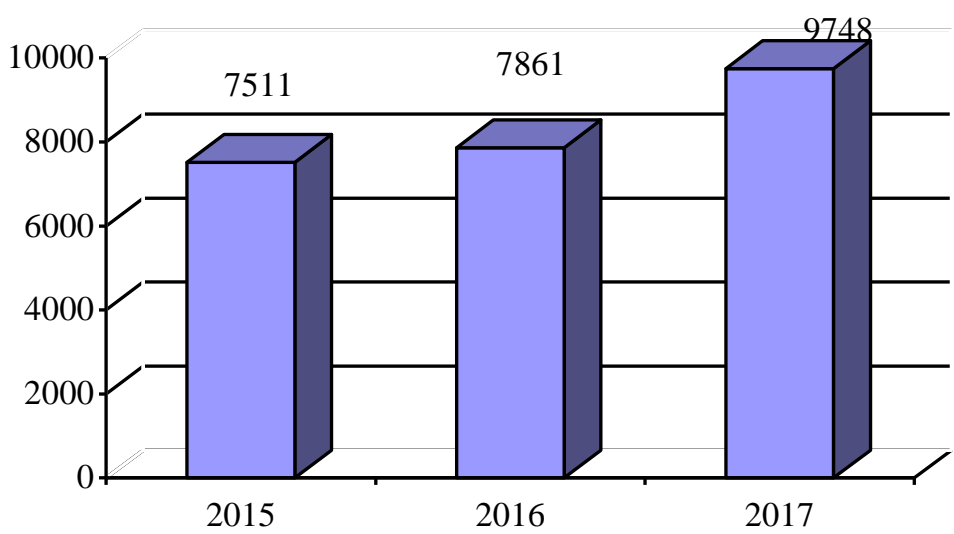

$\square$ кількість укладених договорів
іпотеки

Рис. 2. Динаміка кількості укладених іпотечних договорів житлового будівництва в Україні протягом 2015 - 2017 років*

*Джерело: Міністерство юстиції України.

Перевагами прогам іпотечного кредитування житлового будівництва є:

1) розширення бази потенційних клієнтв;

2) зростання обсягів реалізації об'єктів житлової нерухомості за рахунок іпотечного кредитування;

3) можливість запропонувати потенційному клієнту більш привабливі умови кредитування нижча за середньоринкову ставка кредитування, відсутність додаткових внесків;

4) швидке надходження фінансових ресурсів на рахунки підприємств-забудовниківв;

5) ретельна перевірка банком усіх умов будівництва через акредитацію об'єктів житлової нерухомості;

6) значний термін кредитування, який може становити до 20 років.

Отже, використання кредитних ресурсів у процесі фінансування будівництва житла сприятиме соціально-економічному розвитку країни загалом, а також може виступати у ролі інструмента подолання кризових явищ в економіці. . 3-поміж усіх інструментів кредитного фінансування суттєві переваги для застосування у житловому будівництві має іпотечне кредитування. Позитивний ефект від іпотечного кредитування житлового будівництва полягатиме у наступному: 1) ринок нерухомості акумулює та «пов'язує» суттєві обсяги фінансових ресурсів, що виконуватиме антиінфляційну функцію; 2) використання грошових коштів населенням для придбання житлової нерухомості сприяє створенню додаткової вартості (іпотечний мультиплікатор у 2017 році становив 11,48, тобто кожна гривня іпотечного кредиту збільшує ВВП країни в середньому на 11,48 грн); 3) збільшення обсягів будівництва об'єктів житлової нерухомості призведе до розвитку міст, місцевих будівельних комплексів, а також до створення додаткових робочих місць; 4) зростання обсягів будівництва призводить до зростання ділової активності таких суміжних сферах, як у виробництві будівельних матеріалів та конструкцій, будівельному та дорожному машинобудуванні, деревообробній галузі, виробництві меблів тощо; 5) залучення позикового капіталу у господарський обіг через механізм застави та через вториний ринок заставних цінних паперів $є$ вагомим чинником фінансового оздоровлення економіки [7].

Висновки та пропозиції. У результаті проведеного дослідження можна стверджувати, що використання позикових ресурсів як джерела фінансування житлового будівництва має безперечні переваги, оскільки сприяє насамперед соціально-економічному розвитку країни та сприяє реалізації права кожного громадянина на володіння житлом. Разом з тим, при виборі форми кредитування житлового будівництва доцільно керуватися перевагами та недоліками кожної окремої форми для конкретного об'єкта житлової нерухомості. Наявність виявлених проблемних аспектів у системі фінансування житлового будівництва свідчить про необхідність безперервного дослідження особливостей застосування окремих джерел фінансування будівництва об'єктів житлової нерухомості. 


\section{Джерела та література}

1. Юркевич О.Н. Особливості іпотечного житлового фінансування в Україні на сучасному етапі. Електронне наукове фахове видання "Економіка та суспільство". 2016. №3. С. 497-503. URL:http://www.economy" andsociety.in.ua/journal/3_ukr/85.pdf (дата звернення 19.05.2019)

2. Кравченко В. І., Паливода К. В. Фінансування будівництва житла: Ч. 2. Новітні тенденції. - К.: Вид. дім «Києво-Могилянська академія», 2006.- 132 с.

3. Свтух О.Т. Світовий досвід використання стандартів при іпотечному кредитуванні. Bicник $У A B C$. 2009. № 2. С. 37-39.

4. Грошово-кредитна та фінансова статистика країни. URL: https://bank.gov.ua/control/uk/publish/article?art_id="27843415\&cat_id=44578\#1(дата_ звернення 19.07.2019)

5. Статистичнй збірник "Житлове будівництво в $\quad$ Україні роках".URL:http://www.ukrstat.gov.ua/druk/publicat/kat_u/2018/zb/10/zb_gb2012-2017pdf.pdf （дата звернення 20.05.2019 р.)

6. Капітальні за джерелами фінансування. http://www.ukrstat.gov.ua/operativ/operativ2014/ibd/kindj/iunfin_u/infin04_14u.htm (дата звернення 19.05.2019)

7. Дмітрієва O. Сучасний стан та майбутне іпотечного кредитування. URL: https://knute.edu.ua/file/NjY4NQ==/3c37bccd4f1a5ad5dd66716fdabbe13b.pdf (дата звернення 19.05.2019)

8. Ломачинська I. А. Проблеми та перспективи облігаційних позик як джерела фінансування вітчизняних підприємств: трансакційний http://liber.onu.edu.ua:8080/bitstream/handle/123456789/13681/582-592.pdf?sequence=1\&isAllowed=y (дата звернення 19.05.2019)

\section{References}

1. Yurkevich O.M. (2016), "Current Features of Mortgage Financing in Ukraine", Ekonomika ta suspil'stvo, [Online], vol. 3, available at: http://www.economyandsociety.in.ua/ journal/3_ukr/85.pdf (Accessed 19 May 2019). [in Ukrainian]

2. Kravchenko V. I., Palyvoda K. V. (2006) Finansuvannya budivnytstva zhytla: CH. 2. Novitni tendentsiyi. [Financing of housing construction: Part 2. Recent trends. ] K.: Vyd. dim «Kyyevo-Mohylyans'ka akademiya» - K .: View. House of Kyiv-Mohyla Academy. 132 P. [in Ukrainian]

3. Yevtukh O.T. (2009) Svitovyy dosvid vykorystannya standartiv pry ipotechnomu kredytuvanni [Worldwide experience in using mortgage lending standards] Visnyk UAVS - UBCA Newsletter. (2). P. 37-39. [in Ukrainian]

4. The official site of National Bank of Ukraine (2017), "Monetary and financial statistics of the country", available at: https://bank.gov.ua/control/uk/publish/article?art_"id=27843415\&cat_id=44578\#1(Accessed 19 May 2019) [in Ukrainian]

5. Statystychnyy zbirnyk "Zhytlove budivnytstvo v Ukrayini u 2012-2017 rokakh" (2018) [Statistical collection "Housing in Ukraine in 2012-2017". Retrieved from: http://www.ukrstat.gov.ua/druk/publicat/kat_u/2018/zb/10/zb_gb2012-2017pdf.pdf [in Ukrainian] (Accessed 20 May 2019).

6. Kapital'ni investytsiyi za dzherelamy finansuvannya (2018) [Capital investments by sources of financing]. Retrieved from: http://www.ukrstat.gov.ua/operativ/operativ2014/ibd/kindj/iunfin_u/infin04_14u.htm (Accessed 19 May 2019). [in Ukrainian]

7. Dmitriyeva O. (2017). Suchasnyy stan ta maybutnye ipotechnoho kredytuvannya [The current state and future of mortgage lending]. Retrieved from: https://knute.edu.ua/file/NjY4NQ==/3c37bccd4f1a5ad5dd66716fdabbe13b.pdf (Accessed 19 May 2019). [in Ukrainian]

8. Lomachyns'ka I. A. (2004). Problemy ta perspektyvy oblihatsiynykh pozyk yak dzherela finansuvannya vitchyznyanykh pidpryyemstv: transaktsiynyy analiz [Problems and prospects of bonded loans as a source of financing for domestic enterprises: a transactional analysis]. Retrieved from: http://liber.onu.edu.ua:8080/bitstream/handle/123456789/13681/582-592.pdf?sequence=1\&isAllowed=y (Accessed 19 May 2019). [in Ukrainian] 